\title{
The use of ozone to extend the shelf-life and maintain quality of fresh produce
}

\author{
Marcin Glowacz*, Richard Colgan and Deborah Rees \\ Natural Resources Institute, University of Greenwich, Chatham, ME4 4TB, United Kingdom \\ *Corresponding author. Tel.: +44 (0) 1634883564 \\ E-mail address: M.M.Glowacz@greenwich.ac.uk
}

\begin{abstract}
Fresh produce has been recognised as a healthy food, thus there is increasing consumer demand for fresh fruit and vegetables. Their shelf-life, however, is relatively short and is limited by microbial contamination or visual, textural and nutritional quality loss. There are many methods to reduce/eliminate microorganisms present in food and ozone treatment is one of them. The use of ozone by the fresh produce industry is a good alternative to chemical treatments, e.g. the use of chlorine. The effectiveness of ozone as an antimicrobial agent has previously been reviewed and has been updated here, with the latest findings. The main focus of this review is on the effects of ozone on the fresh produce quality, defined by maintenance of texture, visual quality, taste and aroma, and nutritional content. Furthermore, ozone has been found to be efficient in reducing pesticide residues from the produce. The treatments that have the ability to reduce microbial contamination of the product without having an adverse effect on its visual, textural and nutritional quality can be recommended and subsequently incorporated into the supply chain. A good understanding of all the benefits and limitations related to the use of ozone is needed, and relevant information has been reviewed in this paper.
\end{abstract}

Keywords: ozone, fresh produce, quality and safety, sensory evaluation, storage

\section{INTRODUCTION}

The fresh produce industry is constantly growing, due to increasing consumer demand. Consumers care more and more about what they eat and fresh produce has been recognised as a healthy food, for example being rich in antioxidants. ${ }^{1-3}$ The shelf-life of fresh produce, however, is limited and determined by initial quality at harvest ${ }^{4,5}$ and subsequent storage conditions. ${ }^{6}$ New techniques for reducing undesired microbial contamination, spoilage and decay, as well as maintaining product's visual, textural and nutritional quality are required in all steps of the production and distribution chain. One of the options could be the 
use of ozone, owing to its potential to reduce microbial contamination of the produce. A good understanding of all the benefits and limitations related to ozone use is needed ${ }^{7}$ and this review aims to collate and discuss all the latest findings within this subject area.

\section{OZONE AS AN ANTIMICROBIAL AGENT}

Ozone $\left(\mathrm{O}_{3}\right)$ is a well-known strong oxidizing agent that has been used by the fresh produce industry as an antimicrobial agent for a number of years and has been generally recognised as safe (GRAS) (US FDA, 2001 (http://www.fda.gov/)). In contrast to other sanitizers, it does not leave chemical residues on the surface of the produce, ${ }^{8,9}$ thus the use of ozone has the potential benefits to the food industry. It has been demonstrated in number of studies that microbial contamination can be reduced by applying ozone in either aqueous ${ }^{10-13}$ or gaseous ${ }^{14-17}$ form (Table 1). Physicochemical properties of ozone and its antimicrobial mechanisms of action (effect on cellular constituents such as proteins, lipids, nucleic acids, effect on enzymes and bacterial cell walls) have been described in more depth elsewhere, ${ }^{8,9,18}$ and thus will not be detailed here.

\section{Bacteria}

Treatment of fresh produce with ozonated water prior to storage has been found efficient in reducing microbial counts on numerous products, including apples, ${ }^{10}$ carrots, ${ }^{19}$ celery, ${ }^{20}$ lettuce, ${ }^{11,13,21,22}$ peppers, ${ }^{12,13}$ spinach $^{23,24}$ and strawberries. ${ }^{12,25}$ Exposure to gaseous ozone, on the other hand, was found efficient in reducing microbial counts on blueberries,${ }^{26}$ carrots, ${ }^{27}$ papaya, ${ }^{28}$ peppers, ${ }^{15,29}$ spinach ${ }^{17,30}$ and tomatoes. ${ }^{14,31,32}$ It is worth mentioning, that treatment with ozone reduced human health risk associated with foodborne pathogens, i.e. Escherichia coli, ${ }^{10,23,24,33}$ Listeria sp. ${ }^{12,23,24}$ and Shigella sp. ${ }^{34}$ by reducing their numbers on fresh produce. Some authors, ${ }^{31,35,36}$ however, did not observe reductions in microbial counts in response to ozone treatment. This could be due to cut surfaces that promoted the leaching of organic matter from the product, e.g. from fresh-cut green peppers ${ }^{36}$ or tissue damage if the dose of ozone was too high. ${ }^{37,38}$ Ozone would in that case rather react with organic matter than act as antimicrobial agent ${ }^{39}$ thus being less efficient against the microorganisms. Ketteringham et al. ${ }^{36}$ suggested that whole peppers rather than fresh-cut fruits would be more suitable for ozone treatment.

The level of reduction in microbial counts on carrots and lettuce ${ }^{31}$ was less when compared with tomatoes and was explained by better attachment of bacteria cells to porous and rough surfaces in which bacteria were protected from ozone action. The lack of effect of gaseous ozone treatment at 5 ppm for 315 min on $E$. coli in carrots, ${ }^{31}$ can be explained by the dose of ozone being too low. It has been previously 
reported by others ${ }^{19,27}$ that to reduce microbial contamination of carrots, ozone needs to be applied at $1,000 \mathrm{ppm}$ for $5 \mathrm{~min}$ in its gaseous form, ${ }^{27}$ or about $10 \mathrm{ppm}$ for at least $10 \mathrm{~min}$ when used in the aqueous form. ${ }^{19,27}$ Singh et al..$^{27}$ however did not assess organoleptic properties of the produce, whereas ozone at the dose used in their study is likely to adversely affect other quality characteristics of carrots. ${ }^{40}$ In lettuce, on the other hand, the lack of effect of gaseous ozone treatment at $5 \mathrm{ppm}$ for 3-15 $\mathrm{min}^{31}$ was probably due to the dose of ozone being too high, so that it caused tissue damage and counteracted the beneficial antimicrobial action. Microbial reductions on lettuce have been observed by others when ozonated water was used at $0.5 \mathrm{ppm}$ for 5-30 $\mathrm{min},{ }^{13}$ at 0.5-4.5 ppm for 0.5-3.5 $\mathrm{min},{ }^{38}$ at $2.5-4 \mathrm{ppm}$ for $5 \mathrm{~min},{ }^{21}$ at $4 \mathrm{pm}$ for $2 \min ^{11}$ and at 2.5-7.5 ppm for $10 \mathrm{~min}^{22}$ In some of these studies the doses of ozone were also too high, ${ }^{13,22}$ however sensory evaluation of the produce was either not conducted, ${ }^{13}$ or carried out by a random, untrained panel, ${ }^{22}$ who nonetheless were not pleased with the quality of lettuce treated with ozone, as indicated by their lack of willingness to purchase the product. Olmez and Akbas ${ }^{38}$, who focused on optimization of ozonated water treatment for lettuce, reported that overall visual quality declined with the concentration of ozone being increased above $2.5 \mathrm{ppm}$ and exposure time extended above $2.5 \mathrm{~min}$.

Allende et al. ${ }^{35}$ reported that treatment with gaseous ozone at $5,000 \mathrm{mg} \mathrm{L}^{-1}$ for 6 days had no significant effect on microbial counts in strawberries. However, in their study Allende et al. ${ }^{35}$ observed only low microbial counts $\left(10^{2}-10^{4}\right.$ colony forming units $\left.(\mathrm{cfu}) \mathrm{g}^{-1}\right)$ on both control and ozone-treated strawberries, and microbial growth was not a critical parameter of produce quality, explaining why difference between treatments could not be detected. In contrast, when initial microbial counts on strawberries were higher $\left(10^{7} \mathrm{cfu}^{-1}\right)$, reduction by $1.21 \log$ unit was observed in strawberries washed with ozonated water at $0.3 \mathrm{ppm}$ for $2 \mathrm{~min}^{25}$ and by $2.30 \log$ unit at $2 \mathrm{ppm}$ for $3 \mathrm{~min}$. ${ }^{12}$ The difference between these studies may also be due to the method of ozone application (gaseous ${ }^{35}$ vs. aqueous ${ }^{12,25}$ ).

The efficiency of ozone treatment in reducing microbial counts on fresh produce depends on the dose of ozone being used (dose - ozone concentration $\mathrm{x}$ time of exposure) and on initial microbial counts/inoculum. ${ }^{29,32}$ In the case of aqueous ozone solutions (pre-ozonated water or continuously ozonated water), time of exposure is often limited, ${ }^{10,11,13}$ for practical reasons. Continuously ozonated water was found to be more efficient in reducing microbial counts ${ }^{13}$ compared to pre-ozonated water, which is not surprising, since in pre-ozonated water the concentration of ozone is depleted during the processing stage, e.g. due to contact of ozone with organic matter, while in continuously ozonated water its concentration was maintained throughout the treatment period. With gaseous treatment, on the other 
hand, fruit and vegetables can be treated with high ozone concentration prior to storage ${ }^{28,41}$ or they might be continuously/intermittently exposed ${ }^{14,42}$ to lower ozone concentrations during storage.

The highest microbial reductions are often observed at the highest doses of ozone, ${ }^{12,26,43}$ however, as the sensitivity to ozone varies among different commodities, it is necessary to establish an optimal treatment (dose) for each product ${ }^{44}$ to avoid tissue damage, that among other things leads to an increased susceptibility to microbial infection. A number of studies ${ }^{9,36,45}$ focused on the antimicrobial efficacy of ozone treatment and not on the effects of ozone on nutritional and sensory quality of the product. Only those treatments that reduce microbial contamination of the product without having an adverse effect on product's visual, textural and nutritional quality ${ }^{46,47}$ can be recommended and subsequently incorporated into the supply chain.

\section{Fungi}

Treatment of fresh produce with ozone has reduced fungal development, measured as lesion size, on a number of products, e.g. in apples ${ }^{48}$ exposed to gaseous ozone at $450 \mathrm{ppb}$ for 2 days, in broccoli ${ }^{37}$ continuously exposed to ozone at 200 and $700 \mathrm{ppb}$ for 12 days, in carrots exposed to gaseous ozone at $450 \mathrm{ppb}$ for 2 days ${ }^{48}$ at $1 \mathrm{ppm}$ for 4 days, ${ }^{49}$ intermittently ( $8 \mathrm{~h}$ per day) exposed to ozone at 15 ppm for 4 weeks $^{50}$ or continuously exposed to low level of ozone at 50 ppb over a 6 month storage period. ${ }^{40}$ Fungal development was also reduced in kiwi ${ }^{51,52}$ continuously exposed to ozone at 300 ppb over 4 month storage period, in papaya ${ }^{53}$ exposed to ozone at $0.04,1.6$ and $4 \mathrm{ppm}$ for $48-144 \mathrm{~h}$, in peaches $^{54}$ continuously exposed to ozone at 300 ppb over a 4 week period, in tangerine ${ }^{55}$ exposed to gaseous ozone at $200 \mathrm{ppm}$ for $4-6 \mathrm{~h}$, and in tomatoes ${ }^{56-58}$ continuously exposed to ozone at $0.2,1$ and 5 ppm for up to 13 days, but not in plums ${ }^{59}$ where dose of ozone at $0.1 \mathrm{ppm}$ for 8 days was too low to prevent fungal growth.

It has been demonstrated ${ }^{59}$ that efficiency of ozone exposure in reducing fungal development depends on the product type and inoculum concentration. Tzortzakis et al. ${ }^{59}$ inoculated clementines, tomatoes and plums with Botrytis cinerea spores at low $\left(2 \times 10^{3}\right)$, intermediate $\left(2 \times 10^{5}\right)$ or high $\left(2 \times 10^{7}\right)$ spore concentration. Fruit were subsequently exposed for 8 days to clean air (control) or ozone at 100 ppb. Fungi development was significantly reduced in ozone-exposed clementines at all spore concentrations, whereas in tomatoes a positive effect of ozone was only observed at the highest $\left(2 \times 10^{7}\right)$ inoculum. In contrast, in plums ozone had no effect at either low or high spore concentration. Clearly, not all commodities would benefit from ozone exposure as high doses that might be needed may cause damage to fruit epidermis, facilitating fungal penetration. 
Interestingly, both Liew and Prange $\mathrm{s}^{50}$ and Sharpe et al. ${ }^{48}$ observed reduced growth of gray mould (B. cinerea) and white mould (Sclerotinia sclerotiorum) on ozone treated carrots, whereas others ${ }^{40,49}$ observed better resistance to $B$. cinerea but not to $S$. sclerotorium. The level of isocoumarin 6methoxymellein (3-methyl-6-methoxy-8-hydroxy-3,4-dihydroisocoumarin; 6-MM), which is associated with resistance to $B$. cinerea, was found to be significantly increased in carrots continuously exposed to ozone, even at the dose as low as $50 \mathrm{ppb} .{ }^{40}$ Other mechanisms, however, such as other compounds could have contributed to the improved resistance. ${ }^{49}$ The results reported by different authors ${ }^{40,48-50}$ may vary for several reasons. First of all, the ozone dose of 7.5-60 ppm ( $8 \mathrm{~h}$ per day) for 4 weeks used by Liew and Prange ${ }^{50}$ was higher than $1 \mathrm{ppm}$ for 4 days used by Forney et al. ${ }^{49}$ and $50 \mathrm{ppb}$ over 6 months storage period used by Hildebrand et al. ${ }^{40}$ Even though, the dose of ozone used by Liew and Prange ${ }^{50}$ was found to be fungistatic, it was injurious to the produce as indicated by increased respiration rate, electrolyte leakage, colour changes (orange-red colour appeared to be bleached by the treatment) and surface pitting. Secondly, the duration of storage differed between the studies. In the study of Sharpe et $_{\text {al. }}{ }^{48}$ and Liew and Prange ${ }^{50}$ growth of fungal pathogens (B. cinerea and S. sclerotorium) was assessed over 12 and 28 days, respectively, whereas Forney et $a l .{ }^{49}$ and Hildebrand et $a l .{ }^{40}$ conducted long-term storage trials of up to 6 months, and observed that the growth of S. sclerotiorum was slightly reduced immediately after treatment with ozone at $1 \mathrm{ppm}$ for 4 days ${ }^{49}$ or by continuous exposure to ozone at $50 \mathrm{ppb},{ }^{40}$ but this effect was lost after 4 weeks of storage.

Ozone exposure decreased the disease incidence (\% of fruit that show any degree of spoilage due to fungal infection) in apples treated with ozone at $25 \mathrm{ppm}$ for $30-90 \mathrm{~min},{ }^{60}$ in grapes ${ }^{41,54,61-64}$ exposed to gaseous ozone at $200 \mathrm{ppm}$ for $15 \mathrm{~min}^{62}$ or at 2,500 ppm for $2 \mathrm{~h}, 5,000 \mathrm{ppm}$ for $1 \mathrm{~h}$ and 10,000 for 30 min. ${ }^{41}$ Similarly, decay of grapes was significantly reduced in produce continuously exposed to ozone at $100 \mathrm{ppb}$ for up to 60 days $^{64}$, at 300 ppb over 7 weeks ${ }^{54}$ and in grapes continuously or intermittently $(12 \mathrm{~h}$ per day) exposed to ozone at 2 ppm for 72 days, ${ }^{61}$ in tangerine exposed to gaseous ozone at 200 ppm for 4-6 $\mathrm{h}^{55}$, in strawberries exposed to gaseous ozone at $1.5 \mathrm{ppm}$ for 3 days, ${ }^{65}$ but not when the dose of ozone at $0.35 \mathrm{ppm}$ for 3 days $^{66}$ was too low to prevent decay of strawberries or in blueberries exposed to gaseous ozone at $450 \mathrm{ppb}$ for 2 days. ${ }^{48}$ Sharpe et $a l .{ }^{48}$ found that no effect in blueberries was due to their high susceptibility to fungal infection, when compared with apples, grapes and carrots. Disease incidence in grapes, however, was not reduced when produce continuously exposed to low dose of ozone at 100 $\mathrm{ppb}^{64}$ or $300 \mathrm{ppb}^{54}$ was transferred to ambient temperature, simulating retail conditions. 
Minas et al. ${ }^{52}$ observed reduced disease incidence only in kiwi fruits exposed to ozone at 300 ppb for 8-144 h prior to inoculation with B. cinerea, whereas post-inoculation treatment with ozone had no effect. This finding indicates that exposure of kiwi fruit to ozone may affect fruit-pathogen interaction and enhance their disease resistance. Increased resistance to diseases has also been observed in tomatoes ${ }^{58}$ exposed to gaseous ozone at $50 \mathrm{ppb}$ for 6 days prior to inoculation. This implies that ozone may induce defence responses, such as the synthesis of phytoalexins, ${ }^{63}$ i.e. resveratrol and pterostilbene.

Lower disease incidence in fruit and vegetables exposed to ozone might be partially explained by reduced spore production and viability observed in the majority of studies, ${ }^{48,52,56-58}$ which is of high importance for fresh produce industry, reducing disease spread from injured and infected produce. Care must be taken, however, as ozone exposure - even at high doses - does not provide adequate control of fungal development in wound inoculated fruit, thus often having no effect on disease severity, ${ }^{52,54,67}$ which is usually only delayed by the ozone treatment. Fungal structures already developed within wounds remain protected from the oxidizing effect of ozone due to its limited penetration.

It is apparent that ozone efficiency against fungal pathogens is not only affected by the dose of ozone used but also by several other factors including skin characteristics of the produce (e.g. roughness), sensitivity of the specific fungi to ozone $\mathrm{e}^{57,62}$ and storage conditions, e.g. temperature ${ }^{48,50}$ and relative humidity. ${ }^{62}$ Ozone applied at $60 \mathrm{ppm}$ ( $8 \mathrm{~h}$ per day) for 4 weeks was found to be more efficient in reducing the growth of $B$. cinerea and $S$. sclerotorium on carrots at $2{ }^{\circ} \mathrm{C}$ when compared with $8{ }^{\circ} \mathrm{C} .{ }^{50}$ The reduction rate for both pathogens was 57 and $56 \%$ at $2{ }^{\circ} \mathrm{C}$, and 42 and $37 \%$ at $8{ }^{\circ} \mathrm{C}$, respectively, ${ }^{50}$ which may be associated with slower growth rate of fungi at lower storage temperature. Ozkan et al. ${ }^{62}$ on the other hand, observed that ozone efficiency against conidia of Penicillium digitatum, Penicillium italicum, and $B$. cinerea depended on relative humidity $(\mathrm{RH})$. Treatment with gaseous ozone at $200 \mathrm{ppm}$ for 15 min was sufficient to inhibit conidia germination of all three pathogens at $95 \% \mathrm{RH}$, whereas at $75 \% \mathrm{RH}$ and $35 \%$ $\mathrm{RH}$ the dose of ozone required to achieve similar inhibition had to be increased two and more than ten times, respectively. Ozone efficiency was clearly reduced with decreasing relative humidity.

In summary, ozone reduces microbial contamination of the produce, being more efficient against bacteria than fungi. The disease incidence may not always be reduced in ozone-treated produce; nonetheless ozone exposure reduces the spread of the disease by reducing spore production and viability. Furthermore, it has been reported to induce changes in the produce, i.e. in grapes, kiwi and tomatoes, increasing their disease resistance. 


\section{PESTICIDE RESIDUES}

Pesticides are frequently used to improve crop productivity and health by controlling pests. There is, however, an increasing public concern about health risks associated with the presence of these chemicals on fruit and vegetables. ${ }^{68}$ Furthermore, pesticide residues may affect international trade, due to differences in food policies regarding pesticide use among various countries. ${ }^{69}$

Ozone cannot penetrate deeply into the fruit because fruit surface generally contains many readily oxidizable materials that ozone will react with. The majority of pesticide residues, however, are located in the skin. ${ }^{44}$ The efficiency in pesticide residues removal by ozone varies among different commodities, due to their surface characteristics. ${ }^{70}$

A number of studies have found reductions in pesticide residues in apples washed with ozonated water at 1 and $3 \mathrm{ppm}$ for 5-30 $\mathrm{min}^{71}$ or at $250 \mathrm{ppb}$ for 5-30 min, ${ }^{72}$ in grapes treated with gaseous ozone at $10,000 \mathrm{ppm}$ for $1 \mathrm{~h}^{41}$ or continuously exposed to ozone at $0.3 \mathrm{ppm}$ for 36 days, ${ }^{42}$ in lettuce ${ }^{70,73}$ washed with ozonated water at $0.5-2.0 \mathrm{ppm}$ for 5-20 min, in pak choi ${ }^{74}$ washed with ozonated water at 1.4 or 2.0 ppm for 15-30 min, in strawberries ${ }^{70}$ washed with ozonated water at $2.0 \mathrm{ppm}$ for $10 \mathrm{~min}$, in tomatoes ${ }^{70,73}$ washed with ozonated water at 0.5-2.0 ppm for 5-20 min, and citrus fruit, ${ }^{75}$ i.e. grapefruit, lemon and orange washed with ozonated water at 4-10 ppm for 5 min. Treatment with ozonated water was very efficient in reducing several pesticide residues, including captan (above $92 \%$ reduction in apples), ${ }^{72}$ mancozeb (up to $97 \%$ reduction in apples), ${ }^{71}$ fenitrothion (up to 58,48 and $25 \%$ reduction in lettuce, tomatoes and strawberries, respectively), ${ }^{70,73}$ cypermethrin (up to $60 \%$ reduction in pak choi) ${ }^{74}$, parathion (up to $55 \%$ reduction in pak choi) ${ }^{74}$ and diazinon (up to $50 \%$ reduction in pak choi). ${ }^{74}$ The efficiency of the washing was temperature dependent, ${ }^{72,73,75}$ with higher efficiency being observed with increasing temperature in case of apples, ${ }^{72}$ lettuce ${ }^{73}$ and tomatoes. ${ }^{73}$ Increase in temperature, on the other hand reduced the efficiency in pesticide residues removal from citrus fruit. ${ }^{75}$ In case of apples, the rate of change in captan degradation with temperature increase from 21 to $44{ }^{\circ} \mathrm{C}$ was low (around $7 \%$ ), due to $100 \%$ removal of the pesticide at both temperatures; the only difference was in time needed - at $21{ }^{\circ} \mathrm{C}$ treatment time had to be 10 min longer than at $44{ }^{\circ} \mathrm{C}$. In lettuce and tomatoes, with temperature increase from 15 to $30{ }^{\circ} \mathrm{C}$, the rate of reduction of fenitrothion was increased by $\sim 30 \%$. In case of citrus fruit, with temperature increase from 10 to $40{ }^{\circ} \mathrm{C}$, the efficiency of ozone treatment at $4-10 \mathrm{ppm}$ for 5 min in removal of Tetradifon was reduced by $\sim 50 \%$ in lemon and grapefruit and by $\sim 20 \%$ in orange, whereas removal of Chlorothalonil was not affected by changes in wash water temperature. Nonetheless, 
difference among the commodities in pesticides removal was observed, e.g. ozonated water at 4-10 ppm for 5 min removed 100, 90 and $\sim 40 \%$ of Chlorothalonil from orange, lemon and grapefruit, respectively. This was explained by differences in the diffusion of adsorbed pesticides into the matrix.

The reduction rates were much higher when ozone was used at higher concentration (2,500 $10,000 \mathrm{ppm}$ ) for a short time (up to 2 hours), ${ }^{41}$ but this treatment led to significant damage of the fruit, thus continuous exposure to ozone at low concentration of $300 \mathrm{ppb}$ was suggested ${ }^{42}$ as a more feasible solution for pesticide residues removal. Although gaseous ozone was found to be efficient in reducing pesticide residues, including pyrimethanil, cyprodinil and fenhexamid from grapes, ${ }^{41,42}$ it had no effect on boscalid and iprodione residues, which means that not all pesticides can be removed with ozone treatment. Treatment with gaseous ozone at 10,000 ppm for $1 \mathrm{~h}$ reduced pyrimethanil, cyprodinil and fenhexamid by $\sim 84,75$ and $69 \%$ respectively, whereas the residues of boscalid and iprodione were only reduced by 17 and 5\%. Similarly, in the presence of gaseous ozone at $300 \mathrm{ppb}$, residues of pyrimethanil, cyprodinil and fenhexamid were reduced by $\sim 35,22$ and $23 \%$ respectively, while the residues of boscalid and iprodione were only reduced by 7 and $1 \%$.

\section{WEIGHT LOSS}

Weight loss was reduced in kiwi continuously exposed to ozone at $300 \mathrm{ppb},{ }^{76}$ in papaya exposed to ozone at 1.5-5.0 ppm for 4 days $^{77}$ and strawberries exposed to ozone at $1.5 \mathrm{ppm}$ for 3 days, ${ }^{65}$ while in the majority of studies ozone exposure had no effect. Ali et al. ${ }^{77}$ suggested that this response might be due to thick cuticle of papaya fruit, which prevented the damage of epidermal tissues by ozone action. ${ }^{18}$ It has been shown in several other studies that weight loss was unaffected, for example in broccoli ${ }^{37}$ continuously exposed to ozone at $200 \mathrm{ppb}$, in carrots treated with ozone at $0.3-1 \mathrm{ppm}$ for up to 4 days ${ }^{49}$ or continuously exposed to ozone at $50 \mathrm{ppb}$ for 6 months, ${ }^{40}$ in grapes ${ }^{54}$ continuously exposed to ozone at 300 ppb, in peppers ${ }^{15}$ treated with ozone at $1 \mathrm{ppm}$ for $1-5 \mathrm{~min}$, in rocket leaves ${ }^{78}$ washed with ozone at 10 ppm for $1 \mathrm{~min}$, and in tomatoes ${ }^{79}$ treated with ozone at $10 \mathrm{ppm}$ for $10 \mathrm{~min}$, i.e. when fresh produce was exposed to relatively low concentration of ozone. On the other hand, high dose of ozone caused damage to fruit epidermis, thus leading to higher weight loss in broccoli ${ }^{37}$ continuously exposed to ozone at 700

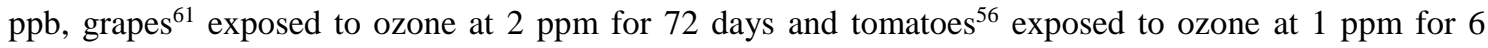
days. These findings suggest that for each commodity there is a threshold in ozone concentration, above which, the exposure may cause the damage to the produce. Based on the limited information available in 
the literature, it can be concluded that these thresholds lie somewhere between 200 and 700 ppb for broccoli, ${ }^{37} 400 \mathrm{ppb}$ and $2 \mathrm{ppm}$ for grapes, ${ }^{54,61}$ and $50 \mathrm{ppb}$ and $1 \mathrm{ppm}$ for tomatoes. ${ }^{56}$

\section{RESPIRATION}

Quality loss during the storage of fresh produce may be accelerated by changes in the metabolic activity of the product. Respiration rate (consumption of $\mathrm{O}_{2}$ and production of $\mathrm{CO}_{2}$ ), which is a measure of physiological activity ${ }^{80}$ increases in response to tissue damage (e.g. during processing stage). Thus, it is not surprising that several authors have reported higher respiration rate as a result of tissue damage due to cutting, e.g. in lettuce ${ }^{81}$ or in tomato slices when compared with whole fruit. ${ }^{14}$

Most studies that used low doses of ozone have shown that ozone treatment did not result in a higher respiration rate in asparagus ${ }^{82}$ broccoli,${ }^{37}$ carrots,${ }^{19}$ celery,${ }^{20}$ lettuce,${ }^{11,21,83}$ peach, ${ }^{54}$ peppers, ${ }^{15}$ rocket leaves, ${ }^{78}$ strawberries $^{35}$ and tomatoes ${ }^{14,56,79}$ unless the dose of ozone used was too high, e.g. 700 ppb in broccoli ${ }^{37}$ which caused damage to the produce.

\section{TEXTURE}

Texture loss during storage is a serious problem because it reduces marketability of the product. A number of authors have studied the effect of ozone on texture maintenance. Most of them found no effect on textural changes in apples,${ }^{84}$ blueberries,${ }^{48}$ cantaloupe,${ }^{85}$ grapes,${ }^{61,63,64}$ lettuce,${ }^{11,21,83}$ pears, ${ }^{84}$ peppers ${ }^{15}$ and rocket leaves. ${ }^{78}$ Several studies, on the other hand found better firmness retention, e.g. in cucumbers continuously exposed to ozone at $40 \mathrm{ppb},{ }^{84}$ in kiwi continuously exposed to ozone at $300 \mathrm{ppb},{ }^{76}$ in papaya exposed to ozone at 1.5-3.5 ppm for 4 days, ${ }^{77}$ strawberries washed with ozonated water at $300 \mathrm{ppb}$ for 2 $\min ^{25}$ or exposed to gaseous ozone at $1.5 \mathrm{ppm}$ for 3 days ${ }^{65}$ and in tomatoes cyclically exposed to gaseous ozone at $4 \mathrm{ppm}$ for $30 \mathrm{~min}$ every $3 \mathrm{~h},{ }^{14}$ exposed to gaseous ozone at $50 \mathrm{ppb}^{56,58}$ or $1 \mathrm{ppm}^{56}$ for 6 days, or treated with gaseous ozone at $10 \mathrm{ppm}$ for $10 \mathrm{~min},{ }^{79}$ where softening of the fruit, associated with ripening, was delayed in ozone-exposed samples. Rodoni et al..$^{79}$ conducted analyses of the cell wall and found a decreased activity of pectin methylesterase (PME) in ozone-exposed tomato fruit. These authors suggested that delayed fruit softening might be due to reduced solubilisation and depolymerisation of pectin polysaccharides. There's clear evidence in literature that ozone may affect both ripening ${ }^{76,77}$ and enzymes, e.g. through signalling molecules. ${ }^{86}$

In a few studies, i.e. in asparagus ${ }^{87}$ and carrots ${ }^{19,49}$ ozone treatment delayed tissue toughening. These changes were associated with changes in cellulose, hemicellulose and lignin content, namely due to reduced lignification of cell walls. The mechanism may involve decreased activity of phenylalanine 
ammonia lyase (PAL; EC 4.3.1.5) as reported in asparagus ${ }^{87}$ washed with ozonated water at $1 \mathrm{ppm}$ for 30 min or reduced activity of polyphenol oxidase (PPO; EC 1.14.18.1) and/or peroxidase (POD; EC 1.11.1.7) as observed in carrots ${ }^{19}$ washed with ozonated water at $10 \mathrm{ppm}$ for $10 \mathrm{~min}$. It could also be associated with changes in the proportion of uronic acids and neutral sugars being present in the watersoluble fraction of pectin. ${ }^{79}$

\section{VISUAL QUALITY}

Visual quality of the product is important because fresh produce with a good appearance is preferred by customers. Any colour alteration might be recognised as a symptom of senescence, ${ }^{6}$ reducing its marketability. Monitoring colour changes during storage is used for determining visual quality loss. Commonly used parameters of colour in 3D colour space are: either (i) hue angle which describes the basic colour, luminance and chroma, i.e. colour saturation ${ }^{88}$ or (ii) lightness (from black to white), greenness/redness and yellowness (from blue to yellow) values. ${ }^{89}$ These parameters have been used to assess colour changes during the storage of various products, e.g. in apples, ${ }^{48}$ broccoli,${ }^{37}$ carrots, ${ }^{31,48}$ grapes ${ }^{64}{ }^{\text {lettuce }}{ }^{11,31}$ and tomatoes. ${ }^{90}$

Ozone treatment had no effect on colour changes during storage in apples, ${ }^{48}$ cucumber ${ }^{84}$ cilantro, ${ }^{91}$ persimmon, ${ }^{92}$ rocket leaves ${ }^{78}$ tangerine ${ }^{55}$ and tomatoes. ${ }^{31,73,79}$ Zambre et al. ${ }^{90}$ however, observed delayed development of red colour during the storage of tomatoes treated with gaseous ozone at 20 to $50 \mathrm{ppm}$ for $10 \mathrm{~min}$. Similar findings have also been reported by others, ${ }^{77}$ who observed that peel colour changes of papaya fruit were affected by exposure to gaseous ozone at $2.5 \mathrm{ppm}$ for $96 \mathrm{~h}$. Exposure to ozone delayed ripening of the fruit, thus extending the shelf-life of papaya and tomatoes, however full colour was not always developed during the storage period.

Continuous exposure to ozone in the range from $40 \mathrm{ppb}^{84}$ to $200 \mathrm{ppb}^{37}$ slowed the process of yellowing of broccoli florets, whereas the concentration of $700 \mathrm{ppb}$ was found to be injurious, ${ }^{37}$ leading to desiccation and tissue browning. Visual quality maintenance was also improved in grapes kept in the presence of $100 \mathrm{ppb}$ of ozone, ${ }^{64}$ when product was subsequently transferred from 0 to $15{ }^{\circ} \mathrm{C}$ (simulating typical retail conditions). In control clusters extreme browning of rachis was observed, grapes became darker and appearance was scored as "poor", whereas in grapes continuously exposed to ozone at 100 ppb, only slight browning of rachis was reported, the change in colour was less pronounced and appearance was scored between "moderate" and "good". 
In carrots treated with ozone at the concentration from 5 to $60 \mathrm{ppm}^{31,50}$ lightness value increased significantly, suggesting that typical orange-red colour was bleached by the treatment. This was further confirmed by the increase in whiteness index. ${ }^{31}$ On the other hand, ozone treatment at $450 \mathrm{ppb}$ had no effect on colour of carrots. ${ }^{48}$ Sharpe et $a l .{ }^{48}$ however, did not measure other quality characteristics, while it was previously reported ${ }^{40}$ that ozone at the concentration as low as $50 \mathrm{ppb}$ may cause an injury to carrot tissue appearing as blotches of brown discoloured periderm. Unfortunately, Hildebrand et al. ${ }^{40}$ did not assess colour changes in their study.

In lettuce, the colour parameters were not affected when samples were treated with ozonated water at concentrations of up to $2 \mathrm{ppm} .{ }^{38,73,83} \mathrm{Olmez}$ and $\mathrm{Akbas}^{38}$ reported that visual quality of lettuce declined when concentration of ozone was above $2.5 \mathrm{ppm}$ and lettuce leaves became translucent when ozonated water at $4.5 \mathrm{ppm}$ was used. Thus, it is not surprising that leaf lightness and whiteness index significantly increased in lettuce leaves, which became translucent after being treated with gaseous ozone at 5 ppm for 15 min. $^{31}$

In several fruit and vegetables, e.g. blueberries,$^{26}$ peppers ${ }^{15}$ and strawberries $25,35,65,66$ the response to ozone depended on the exposure method. Interestingly, colour alterations were observed when ozone was applied at 30,000 ppm for $64 \mathrm{~min}$ in the gaseous form in case of blueberries, which became darker, more red and less blue when compared with untreated samples, and in aqueous form at $1 \mathrm{ppm}$ for 1-5 min in case of peppers which became lighter, whereas ozone treatment had no effect on colour changes in blueberries washed with ozonated water at $21 \mathrm{ppm}$ for 64 min and peppers treated with gaseous ozone at $700 \mathrm{ppb}$ for 1-5 min, respectively. Colour evaluation of blueberries was conducted after the treatment, and it is likely that high dose of ozone used caused significant changes in pigments content, e.g. anthocyanin. In peppers, change in colour due to washing with ozonated water could either be a result of bleaching the pigments from the produce and/or reduced browning due to oxidative processes during storage. In strawberries better colour retention, considered as total colour difference, was found in samples treated with ozonated water at $300 \mathrm{ppb}$ for $2 \mathrm{~min},{ }^{25}$ however, individual colour characteristics, e.g. lightness value, were not provided. Exposure to gaseous ozone at $1.5 \mathrm{ppm}$ for 3 days, on the other hand, had no effect on colour characteristics, ${ }^{65}$ whereas visual quality of strawberries declined, as a result of calyx browning, below the limit of acceptance from the consumers point of view, as assessed by sensory evaluation panel, at high concentration of ozone $-5,000 \mathrm{mg} \mathrm{L}^{-1}$ for 6 days. ${ }^{35}$ 


\section{TASTE AND AROMA}

The taste of the product can be affected by a number of factors, including sugar content and composition, organic acids, acidity and texture-related mouth feel, $, 3,94$ whereas changes in aroma are related to changes in the composition of volatile compounds. ${ }^{66,95,96}$ Both taste and aroma together, define the product's flavour, i.e. the way it is perceived by the customers.

The level of soluble solids is associated with sugar content and fruit maturity. It increases during fruit ripening, and starts to decline when fruit overripe. Most studies have found that ozone treatment had no effect on total soluble solids content in apples, ${ }^{84}$ cantaloupe,${ }^{85}$ carrots,${ }^{40,49}$ celery, ${ }^{20}$ grapes,${ }^{61,64}$ pears, ${ }^{84}$ persimmon, ${ }^{92}$ tangerine ${ }^{55}$ and tomatoes. ${ }^{14}$ On the other hand, a decrease in soluble solids was reported in kiwi fruit continuously exposed to $300 \mathrm{ppb}$ ozone ${ }^{76}$ which suggests that ripening was delayed in ozonetreated fruit. Similarly, delayed increase in soluble solids due to delayed ripening was observed in papaya fruit exposed to a low dose of ozone, between 1.5 and $3.5 \mathrm{ppm}$ for $96 \mathrm{~h},{ }^{77}$ but not when the concentration of ozone was higher, ${ }^{97}$ inhibiting the development of full ripe colour and resulting in tissue damage due to its strong oxidizing activity and thus supporting the growth of fungal pathogens. This underlines the fact that only at certain levels of ozone shelf-life may be extended.

Ozone had no effect on sugars in carrots, ${ }^{40,49}$ celery, ${ }^{20}$ grapes ${ }^{64}$ and kiwi, ${ }^{51}$ however, in some cases sugar content (glucose, fructose) and/or composition was found to be altered in ozone-exposed tomatoes. ${ }^{14,56}$ In the case of whole tomatoes cyclically exposed to gaseous ozone at 4 ppm for 30 min every $3 \mathrm{~h}$, the content of fructose and glucose was not affected after 15 days of storage. In another study, ${ }^{56}$ where tomatoes were stored in the presence of ozone at 0.05 or $1.0 \mathrm{ppm}$ for 6 days, no difference in sugar content was found until the samples were transferred to "clean air" for additional 6 days, when content of fructose, glucose and total soluble sugars was better maintained in ozone-exposed tomatoes, which were perceived sweeter by the sensory evaluation panel when compared with control. ${ }^{56}$ Interestingly, in the case of tomato slices no significant difference in taste was found between treated and untreated samples, even though the content of glucose was significantly higher in ozone-exposed tomatoes. ${ }^{14}$

Regarding organic acids composition, more detailed analyses have only been conducted for kiwi ${ }^{51}$ and tomatoes. ${ }^{14,56}$ In kiwi stored for 29 weeks at $0{ }^{\circ} \mathrm{C}$ in the presence of ozone supplied at $4 \mathrm{mg} \mathrm{h}^{-1}$, no difference was found in ascorbic and tartaric acid when compared with samples stored without ozone. A significant decline, however, was found in citric, malic and quinic acid in ozone-exposed fruit close to 
the end of the storage period, suggesting that ozone-exposed fruit became overripe and organic acids were used as respiratory substrates. In tomatoes exposed to ozone, no difference was observed in ascorbic, citric, malic and succinic acid, ${ }^{14,56}$ while fumaric acid content increased. ${ }^{14}$

Even though some changes in organic acids have been observed, ${ }^{14,51}$ in general, ozone had no effect on acidity of the product in apples, ${ }^{84}$ kiwi, ${ }^{51,76}$ persimmon, ${ }^{92}$ tangerine, ${ }^{55}$ tomatoes ${ }^{79}$ and strawberries. ${ }^{65}$ Artes-Hernandez et al. ${ }^{64}$ did not observe differences in acidity between ozone-exposed (100 ppb for 60 days) and control "Autumn seedless" grapes; however, Cayuela et al. ${ }^{61}$ have demonstrated that these changes depend on the grape variety and method of exposure (continuous, intermittent). In "Regina Victoria" grapes acidity significantly increased in samples continuously or intermittently ( $12 \mathrm{~h}$ per day) exposed to ozone at $2 \mathrm{ppm}$ during storage for 72 days at $5{ }^{\circ} \mathrm{C}$. In "Cardinal" grapes intermittent exposure to ozone had no effect on produce acidity, whereas in continuously exposed grapes acidity increased. Interestingly, in "Superior Seedless" grapes, produce acidity was reduced in response to ozone; reduction being more pronounced in continuously exposed grapes.

The typical aroma of the product was reversibly reduced in tomatoes ${ }^{14}$ cyclically exposed to gaseous ozone at $4 \mathrm{ppm}$ for 30 min every $3 \mathrm{~h}$ and strawberries ${ }^{65,66}$ continuously exposed to gaseous ozone at 0.35 and $1.5 \mathrm{ppm}$ for 3 days, but not affected in cantaloupe ${ }^{85}$ treated with gaseous ozone at $10,000 \mathrm{ppm}$ for $30 \mathrm{~min}$, in grapes ${ }^{64}$ continuously exposed to ozone at $100 \mathrm{ppb}$ for 60 days, and in papaya ${ }^{77}$ treated with ozone at 1.5-5.0 ppm for 4 days. These differences could be due to oxidation of volatiles released by the fruit by ozone molecules ${ }^{65}$ or changes in volatile composition by suppressing their emission, ${ }^{66}$ which is partly associated with delayed ripening. In case of carrots, that were found to be very sensitive to ozone exposure, production of stress volatile compounds (i.e. ethanol, hexanal) has been reported when carrots were exposed to $300-1000$ ppb ozone. ${ }^{49}$

\section{NUTRITIONAL QUALITY}

Plants produce reactive oxygen species (ROS) during cellular metabolism; however, in response to environmental stresses, e.g. ozone, ${ }^{86}$ ROS production, as well as the activity of antioxidant enzymes ascorbate peroxidase (APX; EC 1.11.1.11), catalase (CAT; EC 1.11.1.6) and superoxide dismutase (SOD; EC 1.15.1.1) may increase. ${ }^{98,99}$ ROS include such compounds as superoxide radicals $\left(\mathrm{O}_{2}^{-}\right)$, singlet oxygen $\left({ }^{1} \mathrm{O}_{2}\right)$ and highly reactive hydroxyl radicals $\left(\mathrm{OH}^{-}\right)$. SOD catalyses the dismutation of superoxide $\left(\mathrm{O}_{2}^{-}\right)$to $\mathrm{H}_{2} \mathrm{O}_{2}$ which is then transformed to $\mathrm{H}_{2} \mathrm{O}$ and $\mathrm{O}_{2}$ by simultaneous action of APX and CAT. To mitigate ROS, plants may also induce the biosynthesis of antioxidants, including ascorbic acid (AsA) which is 
involved in the reduction of ROS through the ascorbate-glutathione cycle. ${ }^{100,101}$ Other antioxidants, such as carotenoids and flavonoids have also been suggested to play an important role as ROS scavengers. ${ }^{102,103}$ ROS have also been shown to play a role of signalling molecules. Thus, as a result of cross-talk, they may induce different defence responses within plants, e.g. in response to pathogens or to multiple stresses. ${ }^{101,104}$

The content of ascorbic acid (AsA) was not affected in carrots $^{47}$ and lettuce ${ }^{11}$ washed with ozonated water at $4 \mathrm{ppm}$ for $2 \mathrm{~min}$ and in lettuce and spinach washed with ozonated water at $12 \mathrm{ppm}$ for 15 min. ${ }^{23}$ AsA content was also not affected in whole tomatoes cyclically exposed to gaseous ozone at 4 ppm for 30 min every $3 \mathrm{~h}$ or continuously exposed to ozone at 1 ppm for 6 days ${ }^{14,56}$ but increased in tomato slices. ${ }^{14}$ On the other hand, ozone treatment decreased vitamin $\mathrm{C}$ content in banana ${ }^{1}$ and pineapple. ${ }^{1}$

Increase in AsA content was observed in kiwi fruit stored at $0{ }^{\circ} \mathrm{C}$ for up to 3 months in the presence of ozone at $300 \mathrm{ppb} .^{76}$ Higher AsA content was also found in strawberries treated with low dose of ozone (300-350 ppb) either in gaseous ${ }^{66}$ or aqueous ${ }^{25}$ form and in papaya fruit exposed to gaseous ozone at 1.5-5 ppm for 4 days. ${ }^{77}$ The increase in vitamin $\mathrm{C}$ was observed in celery washed with ozonated water at 30-180 ppb for 5 min. ${ }^{20}$ On the other hand, AsA content was reduced when strawberries were exposed to gaseous ozone at $5,000 \mathrm{mg} \mathrm{L}^{-1}$ for 6 days $^{35}$ and carrots exposed to ozone at 10 ppm for 10 $\min ^{19}$ but not affected in carrots washed with ozonated water at 4 ppm for 2 min. ${ }^{47}$ These findings clearly suggest that changes in AsA content in response to ozone are dose dependent. Changes in AsA content are not surprising as AsA is a key antioxidant in plant tissue ${ }^{101,105}$ and its role is to scavenge ROS that are produced in excess under stress conditions, e.g. high dose of ozone.

Ozone exposure at 2 or $4 \mathrm{ppm}$ for 2 min had no effect on $\beta$-carotene content in lettuce ${ }^{11,38}$ and $\beta$ carotene and lycopene content in tomatoes continuously exposed to ozone at $1 \mathrm{ppm}$ for 6 days ${ }^{56}$ but reduced carotenoid content in carrots washed with ozonated water at $10 \mathrm{ppm}$ for $10 \mathrm{~min} .{ }^{19}$

Total phenolic content was found to increase in ozone treated banana, ${ }^{1}$ grapes, ${ }^{61,63}$ kiwi $^{76}$ and pineapple. ${ }^{1}$ Increase in total phenolics was also observed in response to ozone at $10 \mathrm{ppm}$ for $10 \mathrm{~min}$ in tomatoes, ${ }^{79}$ while ozone at $1 \mathrm{ppm}$ for 6 days had no effect. ${ }^{56}$ The content of total phenolics was found to be higher in papaya exposed to gaseous ozone (1.5-5 ppm for $96 \mathrm{~h}$ prior to ambient storage) when compared with control fruit stored in clean air. ${ }^{77}$ Increase in phenolics was also reported ${ }^{28}$ when papaya was treated with gaseous ozone at $9.2 \mathrm{ppm}$ for 10 or 20 min prior to storage, but not when the exposure 
time (30 min) was too long. This may be explained by antioxidant capacity of phenolic compounds, i.e. if the dose of ozone is too high it could result in excess oxidative stress and production of ROS which then need to be scavenged by antioxidants, e.g. phenolic compounds. Total phenolic content also declined in strawberries exposed to gaseous ozone at $5,000 \mathrm{mg} \mathrm{L}^{-1}$ for 6 days, ${ }^{35}$ these findings suggest that similarly to changes in AsA, the content of phenolic compounds can be affected in response to ozone in a dose dependent manner. Increase in phenolic compounds in response to ozone exposure may be associated with increased activity of phenylalanine ammonia lyase (PAL) or reduced activity of polyphenol oxidase (PPO) and/or peroxidase (POD), which are all involved in polyphenol biochemistry, ${ }^{106}$ e.g. reduced activity of PPO and POD has been reported in carrots washed with ozonated water at 10 ppm for 10 $\min .{ }^{19}$

Antioxidant activity measured as 1, 1-diphenyl-2-picrylhydrazyl (DPPH) free radical-scavenging activity and ferric reducing/antioxidant power (FRAP) was found to increase in ozone-exposed banana, ${ }^{1}$ kiwi ${ }^{76}$ papaya ${ }^{28,77}$ and pineapple. ${ }^{1}$ The increase in antioxidant activity was associated with changes in phenolic compounds. On the other hand, Tzortzakis et al. ${ }^{56}$ did not observe changes in antioxidant activity in tomatoes exposed to $1 \mathrm{ppm}$ ozone for 6 days, which is not surprising as content of AsA, $\beta$ carotene, lycopene and phenolic compounds was not affected. No difference in antioxidant activity was also observed in fresh-cut lettuce and spinach washed with ozonated water at $12 \mathrm{ppm}$ for $15 \mathrm{~min},{ }^{23}$ where the contents of AsA and total phenolics were not affected by the treatment.

\section{INTERACTION WITH ETHYLENE}

In addition to its effect on the produce, it has been observed that ozone can be used in storage rooms to reduce the level of ethylene ${ }^{67,84}$ in the air, delaying the ripening and senescence process and in this way extending the shelf-life of fruits and vegetables. The effect of ethylene on fresh produce quality has been reviewed elsewhere. ${ }^{107}$

\section{CONCLUSIONS}

The use of ozone seems to be a simple and feasible solution for the fresh produce industry. Ozone reduces microbial contamination of the produce and has also been shown to be efficient in removing pesticide residues. Care must be taken because some concentrations of ozone used to reduce microbial contamination and pesticide residues on the fresh produce were higher than those used for produce quality preservation. When used at the proper dose, not too high to cause the damage, ozone treatment may be beneficial to the produce by reducing weight loss, improving texture maintenance and visual quality or 
enhancing its nutritional content. The purpose of this review was to give a clear overview of the findings reported so far on the use of ozone as a postharvest technology to extend the shelf-life and maintain the quality of fresh produce. It is apparent from this work that in number of studies ozone had no adverse effect on the produce quality, while some commodities can clearly benefit from ozone exposure. Thus, further research is necessary to determine the optimal dose of ozone for each commodity of commercial importance. This knowledge would clearly benefit the industry and could be incorporated within the supply chain to extend the shelf-life and/or improve the quality of the produce.

\section{ACKNOWLEDGEMENTS}

This work was supported by the UK Higher Education Innovation Fund.

\section{REFERENCES}

1. Alothman M, Kaur B, Fazilah A, Bhat R and Karim AA, Ozone-induced changes of antioxidant capacity of fresh-cut tropical fruits. Innov Food Sci Emerg Technol 11: 666-671 (2010).

2. Llorach R, Martinez-Sanchez A, Tomas-Barberan FA, Gil MI and Ferreres F, Characterisation of polyphenols and antioxidant properties of five lettuce varieties and escarole. Food Chem 108: 1028-1038 (2008).

3. Pandrangi S and LaBorde LF, Retention of folate, carotenoids, and other quality characteristics in commercially packaged fresh spinach. J Food Sci 69: C702-C707 (2004).

4. Clarkson GJJ, O'Byrne EE, Rothwell SD and Taylor G, Identifying traits to improve postharvest processability in baby leaf salad. Postharvest Biol Tec 30: 287-298 (2003).

5. Zhang FZ, Wagstaff C, Rae AM, Sihota AK, Keevil CW, Rothwell SD, et al., QTLs for shelf life in lettuce co-locate with those for leaf biophysical properties but not with those for leaf developmental traits. J Exp Bot 58: 1433-1449 (2007).

6. Nunes MCN, Emond JP, Rauth M, Dea S and Chau KV, Environmental conditions encountered during typical consumer retail display affect fruit and vegetable quality and waste. Postharvest Biol Tec 51: 232-241 (2009).

7. Artes F, Gomez P, Aguayo E, Escalona V and Artes-Hernandez F, Sustainable sanitation techniques for keeping quality and safety of fresh-cut plant commodities. Postharvest Biol Tec 51: 287-296 (2009).

8. Guzel-Seydim ZB, Greene AK and Seydim AC, Use of ozone in the food industry. LWT - Food Sci Technol 37: 453-460 (2004). 
9. Khadre MA, Yousef AE and Kim JG, Microbiological aspects of ozone applications in food: a review. J Food Sci 66: 1242-1252 (2001).

10. Achen M and Yousef AE, Efficacy of ozone against Escherichia coli O157:H7 on apples. J Food Sci 66: 1380-1384 (2001).

11. Akbas MY and Olmez H, Effectiveness of organic acid, ozonated water and chlorine dippings on microbial reduction and storage quality of fresh-cut iceberg lettuce. J Sci Food Agric 87: 26092616 (2007).

12. Alexandre EMC, Santos-Pedro DM, Brandao TRS and Silva CLM, Influence of aqueous ozone, blanching and combined treatments on microbial load of red bell peppers, strawberries and watercress. J Food Eng 105: 277-282 (2011).

13. Alexopoulos A, Plessas S, Ceciu S, Lazar V, Mantzourani I, Voidarou C, et al., Evaluation of ozone efficacy on the reduction of microbial population of fresh cut lettuce (Lactuca sativa) and green bell pepper (Capsicum annuum). Food Control 30: 491-496 (2013).

14. Aguayo E, Escalona VH and Artes F, Effect of cyclic exposure to ozone gas on physicochemical, sensorial and microbial quality of whole and sliced tomatoes. Postharvest Biol Tec 39: 169-177 (2006).

15. Horvitz S and Cantalejo MJ, Effects of ozone and chlorine postharvest treatments on quality of fresh-cut red bell peppers. Int J Food Sci Technol 47: 1935-1943 (2012).

16. Selma MV, Ibanez AM, Cantwell M and Suslow T, Reduction by gaseous ozone of Salmonella and microbial flora associated with fresh-cut cantaloupe. Food Microbiol 25: 558- 565 (2008).

17. Vurma M, Pandit RB, Sastry SK and Yousef AE, Inactivation of Escherichia coli O157:H7 and natural microbiota on spinach leaves using gaseous ozone during vacuum cooling and simulated transportation. Journal Food Prot 72: 1538-1546 (2009).

18. Forney CF, Postharvest response of horticultural products to ozone, in Postharvest Oxidative Stress in Horticultural Crops, ed. by Hodges DM. Food Products Press, New York, pp. 13-54 (2003).

19. Chauhan OP, Raju PS, Ravi N, Singh A and Bawa AS, Effectiveness of ozone in combination with controlled atmosphere on quality characteristics including lignification of carrot sticks. $J$ Food Eng 102: 43-48 (2011). 
20. Zhang L, Lu Z, Yu Z and Gao X, Preservation of fresh-cut celery by treatment of ozonated water. Food Control 16: 279-283 (2005).

21. Beltran D, Selma MV, Marin A and Gil MI, Ozonated water extends the shelf life of fresh-cut lettuce. J Agric Food Chem 53: 5654-5663 (2005).

22. Garcia A, Mount JR and Davidson PM, Ozone and chlorine treatment of minimally processed lettuce. J Food Sci 68: 2747-2751 (2003).

23. Karaca $\mathrm{H}$ and Velioglu YS, Effects of ozone treatments on microbial quality and some chemical properties of lettuce, spinach, and parsley. Postharvest Biol Tec 88: 46-53 (2014).

24. Rahman SME, Ding $\mathrm{T}$ and $\mathrm{Oh} \mathrm{DH}$, Inactivation effect of newly developed low concentration electrolyzed water and other sanitizers against microorganisms on spinach. Food Control 21: 1383-1387 (2010).

25. Alexandre EMC, Brandao TRS and Silva CLM, Efficacy of non-thermal technologies and sanitizer solutions on microbial load reduction and quality retention of strawberries. $J$ Food Eng 108: 417-426 (2012).

26. Bialka KL and Demirci A, Decontamination of Escherichia coli O157:H7 and Salmonella enterica on blueberries using ozone and pulsed UV-light. J Food Sci 72: M391-396 (2007).

27. Singh N, Singh RK, Bhunia AK and Stroshine RL, Efficacy of chlorine dioxide, ozone, and thyme essential oil or a sequential washing in killing Escherichia coli O157:H7 on lettuce and baby carrots. LWT - Food Sci Technol 35: 720-729 (2002).

28. Yeoh WK, Ali A and Forney CF, Effects of ozone on major antioxidants and microbial populations of fresh-cut papaya. Postharvest Biol Tec 89: 56-58 (2014).

29. Han Y, Floros JD, Linton RH, Nielsen SS and Nelson PE, Response surface modeling for the inactivation of Escherichia coli O157:H7 on green peppers (Capsicum annuum) by ozone gas treatment. J Food Sci 67: 1188-1193 (2002).

30. Klockow PA and Keener KM, Safety and quality assessment of packaged spinach treated with a novel ozone-generation system. LWT - Food Sci Technol 42: 1047-1053 (2009).

31. Bermudez-Aguirre D and Barbosa-Canovas GV, Disinfection of selected vegetables under nonthermal treatments: chlorine, acid citric, ultraviolet light and ozone. Food Control 29: 82-90 (2013). 
32. Das E, Gurakan GC and Bayindirli A, Effect of controlled atmosphere storage, modified atmosphere packaging and gaseous ozone treatment on the survival of Salmonella enteritidis on cherry tomatoes. Food Microbiol 23: 430-438 (2006).

33. Yuk HG, Yoo MY, Yoon JW, Moon KD, Marshall DL and Oh DH, Effect of combined ozone and organic acid treatment for control of Escherichia coli O157:H7 and Listeria monocytogenes on lettuce. J Food Sci 71: M83-87 (2006).

34. Selma MV, Beltran D, Allende A, Chacon-Vera E and Gil MI, Elimination by ozone of Shigella sonnei in shredded lettuce and water. Food Microbiol 24: 492-499 (2007).

35. Allende A, Marin A, Buendia B, Tomas-Barberan F and Gil MI, Impact of combined postharvest treatments (UV-C light, gaseous $\mathrm{O}_{3}$, superatmospheric $\mathrm{O}_{2}$ and high $\mathrm{CO}_{2}$ ) on health promoting compounds and shelf-life of strawberries. Postharvest Biol Tec 46: 201-211 (2007).

36. Ketteringham L, Gausseres R, James SJ and James C, Application of aqueous ozone for treating pre-cut green peppers (Capsicum annuum L.). J Food Eng 76: 104-111 (2006).

37. Forney CF, Song J, Fan L, Hildebrand PD and Jordan MA, Ozone and 1-methylcyclopropene alter the postharvest quality of broccoli. J Am Soc Hortic Sci 128: 403-408 (2003).

38. Olmez H and Akbas MY, Optimization of ozone treatment of fresh-cut green leaf lettuce. J Food Eng 90: 487-494 (2009).

39. Kim JG, Yousef AE and Chism GW, Use of ozone to inactivate microorganisms on lettuce. $J$ Food Safety 19: 17-34 (1999).

40. Hildebrand PD, Forney CF, Song J, Fan L and McRae KB, Effect of a continuous low ozone exposure $\left(50 \mathrm{~nL} \mathrm{~L}^{-1}\right)$ on decay and quality of stored carrots. Postharvest Biol Tec 49: 397-402 (2008).

41. Mlikota Gabler F, Smilanick JL, Mansour MF and Karaca H, Influence of fumigation with high concentrations of ozone gas on postharvest gray mold and fungicide residues on table grapes. Postharvest Biol Tec 55: 85-90 (2010).

42. Karaca H, Walse SS and Smilanick JL, Effect of continuous $0.3 \mu \mathrm{L} / \mathrm{L}$ gaseous ozone exposure on fungicide residues on table grape berries. Postharvest Biol Tec 64: 154-159 (2012).

43. Kim JG and Yousef AE, Inactivation kinetics of foodborne spoilage and pathogenic bacteria by ozone. J Food Sci 65: 521-528 (2000).

44. Karaca H, Use of ozone in the citrus industry. Ozone-Sci Eng 32: 122-129 (2010). 
45. Kim C and Hung YC, Inactivation of E. coli O157:H7 on blueberries by electrolyzed water, ultraviolet light, and ozone. J Food Sci 77: M206-211 (2012).

46. Allende A, Selma MV, Lopez-Galvez F, Villaescusa R and Gil MI, Role of commercial sanitizers and washing systems on epiphytic microorganisms and sensory quality of fresh-cut escarole and lettuce. Postharvest Biol Tec 49: 155-163 (2008).

47. Hassenberg K, Frohling A, Geyer M, Schluter O and Herppich WB, Ozonated wash water for inhibition of Pectobacterium carotovorum on carrots and the effect on the physiological behaviour of produce. Eur J Hortic Sci 73: 37-42 (2008).

48. Sharpe D, Fan L, McRae K, Walker B, MacKay R and Doucette C, Effects of ozone treatment on Botrytis cinerea and Sclerotinia sclerotiorum in relation to horticultural product quality. $J$ Food Sci 74: M250-257 (2009).

49. Forney CF, Song J, Hildebrand PD, Fan L and McRae KB, Interactive effects of ozone and 1methylcyclopropene on decay resistance and quality of stored carrots. Postharvest Biol Tec 45: 341-348 (2007).

50. Liew CL and Prange RK, Effect of ozone and storage temperature on postharvest diseases and physiology of carrots (Daucus carota L.). J Am Soc Hortic Sci 119: 563-567 (1994).

51. Barboni T, Cannac M and Chiaramonti N, Effect of cold storage and ozone treatment on physicochemical parameters, soluble sugars and organic acids in Actinidia deliciosa. Food Chem 121: 946-951 (2010).

52. Minas IS, Karaoglanidis GS, Manganaris GA and Vasilakakis M, Effect of ozone application during cold storage of kiwifruit on the development of stem-end rot caused by Botrytis cinerea. Postharvest Biol Tec 58: 203-210 (2010).

53. Ong MK, Kazi FK, Forney CF and Ali A, Effect of gaseous ozone on papaya anthracnose. Food Bioprocess Tech 6: 2996-3005 (2013).

54. Palou L, Crisosto CH, Smilanick JL, Adaskaveg JE and Zoffoli JP, Effects of continuous 0.3 ppm ozone exposure on decay development and physiological responses of peaches and table grapes in cold storage. Postharvest Biol Tec 24: 39-48 (2002).

55. Boonkorn $\mathrm{P}$, Gemma H, Sugaya $\mathrm{S}$, Setha $\mathrm{S}$, Uthaibutra $\mathrm{J}$ and Whangchai K, Impact of high-dose, short periods of ozone exposure on green mold and antioxidant enzyme activity of tangerine fruit. Postharvest Biol Tec 67: 25-28 (2012). 
56. Tzortzakis N, Borland A, Singleton I and Barnes J, Impact of atmospheric ozone-enrichment on quality-related attributes of tomato fruit. Postharvest Biol Tec 45: 317-325 (2007).

57. Tzortzakis N, Singleton I and Barnes J, Impact of low-level atmospheric ozone-enrichment on black spot and anthracnose rot of tomato fruit. Postharvest Biol Tec 47: 1-9 (2008).

58. Tzortzakis N, Taybi T, Roberts R, Singleton I, Borland A and Barnes J, Low-level atmospheric ozone exposure induces protection against Botrytis cinerea with down-regulation of ethylene-, jasmonate- and pathogenesis-related genes in tomato fruit. Postharvest Biol Tec 61: 152-159 (2011).

59. Tzortzakis N, Singleton I and Barnes J, Deployment of low-level ozone-enrichment for the preservation of chilled fresh produce. Postharvest Biol Tec 43: 261-270 (2007).

60. Puia C, Oroian I and Florian V, Effect of ozone exposure on phytopathogenic microorganisms on stored apples. J Agr Sci 15: 9-13 (2004).

61. Cayuela JA, Vazquez A, Perez AG and Garcia JM, Control of table grapes postharvest decay by ozone treatment and resveratrol induction. Food Sci Technol Int 15: 495-502 (2009).

62. Ozkan R, Smilanick JL and Karabulut OA, Toxicity of ozone gas to conidia of Penicillium digitatum, Penicillium italicum, and Botrytis cinerea and control of gray mold on table grapes. Postharvest Biol Tec 60: 47-51 (2011).

63. Sarig P, Zahavi T, Zutkhi Y, Yannai S, Lisker N and Ben-Arie R, Ozone for control of postharvest decay of table grapes caused by Rhizopus stolonifer. Physiol Mol Plant P 48: 403-415 (1996).

64. Artes-Hernandez F, Aguayo E and Artes F, Alternative atmosphere treatments for keeping quality of 'Autumn seedless' table grapes during long-term cold storage. Postharvest Biol Tec 31: 59-67 (2004).

65. Nadas A, Olmo M and Garcia JM, Growth of Botrytis cinerea and strawberry quality in ozoneenriched atmospheres. J Food Sci 68: 1798-1802 (2003).

66. Perez AG, Sanz C, Rios JJ, Olias R and Olias JM, Effects of ozone treatment on postharvest strawberry quality. J Agric Food Chem 47: 1652-1656 (1999).

67. Palou L, Smilanick JL, Crisosto CH and Mansour M, Effect of gaseous ozone exposure on the development of green and blue molds on cold stored citrus fruit. Plant Disease 85: 632-638 (2001). 
68. Nasreddine L and Parent-Massin D, Food contamination by metals and pesticides in the European Union. Should we worry? Toxicol Lett 127: 29-41 (2002).

69. Drogue S and DeMaria F, Pesticide residues and trade, the apple of discord? Food Policy 37: 641-649 (2012).

70. Ikeura H, Kobayashi F and Tamaki M, Removal of residual pesticides in vegetables using ozone microbubbles. J Hazard Mater 186: 956-959 (2011).

71. Hwang ES, Cash JN and Zabik MJ, Postharvest treatments for the reduction of mancozeb in fresh apples. J Agric Food Chem 49: 3127-3132 (2001).

72. Ong KC, Cash JN, Zabik MJ, Siddiq M and Jones AL, Chlorine and ozone washes for pesticide removal from apples and processed apple sauce. Food Chem 55: 153-160 (1996).

73. Ikeura $\mathrm{H}$, Kobayashi $\mathrm{F}$ and Tamaki $\mathrm{M}$, Ozone microbubble treatment at various water temperatures for the removal of residual pesticides with negligible effects on the physical properties of lettuce and cherry tomatoes. J Food Sci 78: T350-355 (2013).

74. Wu J, Luan T, Lan C, Lo TWH and Chan GYS, Removal of residual pesticides on vegetable using ozonated water. Food Control 18: 466-472 (2007).

75. Kusvuran E, Yildirim D, Mavruk F and Ceyhan M, Removal of chloropyrifos ethyl, tetradifon and chlorothalonil pesticide residues from citrus by using ozone. J Hazard Mater 241-242: 287300 (2012).

76. Minas IS, Tanou G, Belghazi M, Job D, Manganaris GA., Molassiotis A, et al., Physiological and proteomic approaches to address the active role of ozone in kiwifruit post-harvest ripening. $J$ Exp Bot 63: 2449-2464 (2012).

77. Ali A, Ong MK and Forney CF, Effect of ozone pre-conditioning on quality and antioxidant capacity of papaya fruit during ambient storage. Food Chem 142: 19-26 (2014).

78. Martinez-Sanchez A, Allende A, Cortes-Galera Y and Gil MI, Respiration rate response of four baby leaf. Brassica species to cutting at harvest and fresh-cut washing. Postharvest Biol Tec 47: 382-388 (2008).

79. Rodoni L, Casadei N, Concellon A, Alicia ARC and Vicente AR, Effect of short-term ozone treatments on tomato (Solanum lycopersicum L.) fruit quality and cell wall degradation. J Agric Food Chem 58: 594-599 (2010). 
80. Pirovani ME, Piagentini AM, Guemes DR and Di Pentima JH, Quality of minimally processed lettuce as influenced by packaging and chemical treatment. J Food Quality 21: 475-484 (1998).

81. King AD, Magnuson JA, Torok T and Goodman N, Microbial flora and storage quality of partially processed lettuce. J Food Sci 56: 459-461 (1991).

82. Huyskens-Keil S, Hassenberg K and Herppich WB, Impact of postharvest UV-C and ozone treatment on textural properties of white asparagus (Asparagus officinalis L.). J Appl Bot Food Qual 84: 229 - 234 (2011).

83. Baur S, Klaiber RG, Koblo A and Carle R, Effect of different washing procedures on phenolic metabolism of shredded, packaged iceberg lettuce during storage. J Agric Food Chem 52: 70177025 (2004).

84. Skog LJ and Chu CL, Effect of ozone on qualities of fruits and vegetables in cold storage. Can J Plant Sci 81: 773-778 (2001).

85. Selma MV, Ibanez AM, Allende A, Cantwell M and Suslow T, Effect of gaseous ozone and hot water on microbial and sensory quality of cantaloupe and potential transference of Escherichia coli O157:H7 during cutting. Food Microbiol 25: 162-168 (2008).

86. Kangasjarvi J, Jaspers P and Kollist H, Signalling and cell death in ozone-exposed plants. Plant Cell Environ 28: 1021-1036 (2005).

87. An J, Zhang $\mathrm{M}$ and $\mathrm{Lu} \mathrm{Q}$, Changes in some quality indexes in fresh-cut green asparagus pretreated with aqueous ozone and subsequent modified atmosphere packaging. J Food Eng 78: 340-344 (2007).

88. Clydesdale FM, Colorimetry - methodology and applications. Crit Rev Food Sci Nutr 10: 243301 (1978).

89. Abbott JA, Quality measurement of fruits and vegetables. Postharvest Biol Tec 15: 207-225 (1999).

90. Zambre SS, Venkatesh KV and Shah NG, Tomato redness for assessing ozone treatment to extend the shelf life. J Food Eng 96: 463-468 (2010).

91. Wang $\mathrm{H}$, Feng $\mathrm{H}$ and Luo $\mathrm{Y}$, Microbial reduction and storage quality of fresh-cut cilantro washed with acidic electrolyzed water and aqueous ozone. Food Res Int 37: 949-956 (2004).

92. Salvador A, Abad I, Arnal L and Martinez-Javega JM, Effect of ozone on postharvest quality of persimmon. J Food Sci 71: S443-446 (2006). 
93. Eggink PM, Maliepaard C, Tikunov Y, Haanstra JPW, Bovy AG and Visser RGF, A taste of sweet pepper: volatile and non-volatile chemical composition of fresh sweet pepper (Capsicum annuиm) in relation to sensory evaluation of taste. Food Chem 132: 301-310 (2012).

94. Piombino P, Sinesio F, Moneta E, Cammareri M, Genovese A, Lisanti MT, et al., Investigating physicochemical, volatile and sensory parameters playing a positive or a negative role on tomato liking. Food Res Int 50: 409-419 (2013).

95. Feudo GL, Macchione B, Naccarato A, Sindona G and Tagarelli A, The volatile fraction profiling of fresh tomatoes and triple concentrate tomato pastes as parameter for the determination of geographical origin. Food Res Int 44: 781-788 (2011).

96. Leon-Sanchez FD, Pelayo-Zaldivar C, Rivera-Cabrera F, Ponce-Valadez M, Avila-Alejandre X, Fernandez FJ, Escalona-Buendia HB, et al., \& Perez-Flores, L. J. Effect of refrigerated storage on aroma and alcohol dehydrogenase activity in tomato fruit. Postharvest Biol Tec 54: 93-100 (2009).

97. Bataller M, Gonzalez JE, Veliz E and Fernandez LA, Ozone applications in the post-harvest of papaya (Carica papaya L.): an alternative to Amistar fungicide. Ozone-Sci Eng 34: 151-155 (2012).

98. Eraslan F, Inal A, Savasturk O and Gunes A, Changes in antioxidative system and membrane damage of lettuce in response to salinity and boron toxicity. Sci Hortic 114: 5-10 (2007).

99. Tsang EWT, Bowler C, Herouart D, Vancamp W, Villarroel R, Genetello C, et al., Differential regulation of superoxide dismutases in plants exposed to environmental stress. Plant Cell 3: 783792 (1991).

100. Meyer AJ, The integration of glutathione homeostasis and redox signaling. J Plant Physiol 165: 1390-1403 (2008).

101. Mittler R, Oxidative stress, antioxidants and stress tolerance. Trends Plant Sci 7: 405-410 (2002).

102. Chu YH, Chang CL and Hsu HF, Flavonoid content of several vegetables and their antioxidant activity. J Sci Food Agric 80: 561-566 (2000).

103. Hernandez I, Alegre L, Van Breusegem F and Munne-Bosch S, How relevant are flavonoids as antioxidants in plants? Trends Plant Sci 14: 125-132 (2009). 
104. Fujita M, Fujita Y, Noutoshi Y, Takahashi F, Narusaka Y, Yamaguchi-Shinozaki K, et al., Crosstalk between abiotic and biotic stress responses: a current view from the points of convergence in the stress signaling networks. Curr Opin Plant Biol 9: 436-442 (2006).

105. Conklin PL, Recent advances in the role and biosynthesis of ascorbic acid in plants. Plant Cell Environ 24: 383-394 (2001).

106. Toivonen PMA and Brummell DA, Biochemical bases of appearance and texture changes in fresh-cut fruit and vegetables. Postharvest Biol Tec 48: 1-14 (2008).

107. Saltveit ME, Effect of ethylene on quality of fresh fruits and vegetables. Postharvest Biol Tec 15: 279-292 (1999). 